\title{
$H$-Point Standard Addition Method for Simultaneous Spectrophotometric Determination of Cobalt and Nickel Using 3-Hydroxy-3-phenyl-1-(4-trifluoro- methylphenyl)triazene
}

\author{
MANGILAL REGAR, PRABHAT K. BAROLIYA*, \\ R. S. CHAUHAN and A. K. GOSWAMI \\ Department of Chemistry, Mohanlal Sukhadiya University Udaipur, India \\ pbaroliya@yahoo.com
}

Received 7 January 2016 / Accepted 8 February 2016

\begin{abstract}
Simultaneous spectrophotometric determination of cobalt and nickel by $H$-point standard addition method (HPSAM) is described. The method was based on different colour reactions of 3-hydroxy-3-phenyl-1-(4-trifluoromethyl phenyl)triazene (HPTPT) with cobalt and nickel in aqueous medium at $\mathrm{pH} 7.5-9.0$ in the presence of surfactant triton $\mathrm{x}-100$ at two wavelength 410 and $445 \mathrm{~nm}$. Experimental conditions such as colour development, reagent concentration, $\mathrm{pH}$ of the medium were optimized. The developed method has also been successfully applied to spectrophotometric determination of $\mathrm{Co}^{2+}$ and $\mathrm{Ni}^{2+}$ in synthetic samples with RSD of 0.55 and $0.10 \%$, respectively.
\end{abstract}

Keywords: Hydroxytriazenes, Simultaneous Spectrophotometry, Cobalt, Nickel

\section{Introduction}

Hydroxytriazenes are one of the most common chelating agents widely used as reagent is spectrophotometric determination of transition metals ${ }^{1-4}$. It is well known that cobalt is always found in nature in association with nickel ${ }^{5}$. They are essential trace elements in human diet ${ }^{6}$. Several methods for simultaneous determination of $\mathrm{Co}^{2+}$ and $\mathrm{Ni}^{2+}$ have been reported including $\mathrm{HPLC}^{7}$, atomic absorption spectroscopy (AAS) ${ }^{8}$, electrothermal atomic absorption spectroscopy (ETAAS) ${ }^{9}$, flame atomic absorption spectroscopy (FAAS) ${ }^{10}$, x-ray fluorescence $(\mathrm{XRF})^{11}$ and differential pulse polarography (DDP) ${ }^{12}$ etc. Most widely used technique is spectrophotometric determination due to its simplicity and broad application. A few spectrophotomteric methods have been developed for simultaneous spectrophotometric determination cobalt and nickel using colour developing reagents ${ }^{13,14}$. In view of its significant application the present work reports a sensitive HPSAM method for simultaneous determination of cobalt and nickel using hydroxytriazenes. 


\section{Experimental}

HPTPT was synthesized by the standard method as reported ${ }^{15-18}$. In this method nitrobenzene $(50 \mathrm{mmol})$ was reduced with $\mathrm{Zn}$ dust $(10 \mathrm{~g})$ in the presence of $\mathrm{NH}_{4} \mathrm{Cl}(2.76 \mathrm{~g})$ at $50-60{ }^{\circ} \mathrm{C}$ to obtain the phenyl hydroxylamine. The diazotized product was obtained by adding sodium nitrite $(3 \mathrm{~g})$ in small portions to 4-aminobenzotriflouride $(50 \mathrm{mmol})$ dissolved in a mixture of $\mathrm{HCl}(8 \mathrm{~mL})$ and water $(10 \mathrm{~mL})$ at $0-5{ }^{\circ} \mathrm{C}$ with constant magnetic stirring. The diazonium salts was coupled with the phenyl hydroxylamine at $0-5{ }^{\circ} \mathrm{C}$ under constant stirring with occasional addition of sodium acetate solution to maintain the $\mathrm{pH}$ close to 5. After coupling, the resulting product was purified by recrystallization from absolute alcohol. The compound was identified by recording M.P, IR, NMR and MASS spectra.

\section{Apparatus}

UV-Visible absorbance spectra of Co-HT and Ni-HT were recorded on an Elico SL-210 double beam scanning spectrophotometer using a $1.0 \mathrm{~cm}$ path length quartz cell. A Digital Pen $\mathrm{pH}$-meter having glass electrode was used for $\mathrm{pH}$ measurements.

\section{Reagents}

Standard $\mathrm{Co}^{2+}$ and $\mathrm{Ni}^{2+}$ solutions $(\mathrm{M} / 100)$ were prepared by dissolving an appropriate amount of hydrated $\mathrm{Co}^{+2}$ and $\mathrm{Ni}^{2+}$ nitrate salt in a volumetric flask. The solutions were standardized by complexometric titration method. An alcoholic solution of the HPTPT $(\mathrm{M} / 100)$ was prepared fresh as and when required. The $\mathrm{pH}$ of the working solution was adjusted using Tris buffer.

\section{Procedure}

\section{Individual calibration}

In a $10 \mathrm{~mL}$ volumetric flask, $5.0 \mathrm{~mL}$ of hydroxytriazene $(\mathrm{M} / 1000)$ solution, $2 \mathrm{~mL}$ of triton $\mathrm{x}-100(10 \%), 1 \mathrm{~mL}$ of tris buffer solution (1\%) and an appropriate amount of sample solution containing $\mathrm{Co}^{+2}$ and $\mathrm{Ni}^{+2}$ were added. The concentration range of $\mathrm{Co}^{+2}$ and $\mathrm{Ni}^{+2}$ was taken between $1 \times 10^{-6}-50 \times 10^{-6}$ for each complex. The absorbance were measured at $426 \mathrm{~nm}$ against a reagent blank for both $\mathrm{Co}^{2+}$ and $\mathrm{Ni}^{2+}$.

\section{H-point standard addition method}

Mixtures of synthetic solutions having different concentration of cobalt and nickel were prepared from standard solutions. For simultaneous determination of $\mathrm{Co}^{2+}$ and $\mathrm{Ni}^{2+}, 0.4 \mathrm{~mL}$ of synthetic mixture, $5 \mathrm{~mL}$ of $1 \times 10^{-3} \mathrm{M}$ hydroxytriazenes, $2 \mathrm{~mL}$ of triton $\mathrm{x}-100(10 \%)$ and $2 \mathrm{~mL}$ of tris buffer $(1 \%)$ were added in a $10 \mathrm{~mL}$ volumetric flask and standard additions of $\mathrm{Co}^{2+}$, $1 \times 10^{-5}$ to $5 \times 10^{-5}$ were made. The solution was diluted to $10 \mathrm{~mL}$ with water and allowed to stand for $10 \mathrm{~min}$ at room temperature $\left(25^{\circ} \mathrm{C}\right)$. A portion of the solution was then transferred into a 1 $\mathrm{cm}$ quartz cell to measure the absorbance against a reagent blank at the appropriate wavelengths. Using HPSAM, the simultaneous determination of $\mathrm{Co}^{2+}$ and $\mathrm{Ni}^{2+}$ was performed by measuring the absorbance at 410 and $445 \mathrm{~nm}$ with the standard addition of $\mathrm{Co}^{2+}$ solution and graphed to ascertain the concentration of $\mathrm{Co}^{2+}$ in mixture. Two straight lines for concentration and absorption were plotted and the values for the absorption and concentration at the intersection of these two lines termed $\mathrm{CH}$ and $\mathrm{AH}$, respectively, were obtained by extrapolation.

\section{Result and Discussion}

\section{Characterization of 3-hydroxy-3-phenyl-1-(4-trifluoromethylphenyl)triazene (HPTPT)}

The presence of following characteristic absorption bands in infra red and ${ }^{1} \mathrm{H}$ NMR and Mass spectrum confirms the purity of HPTPT. The HPTPT reacts with cobalt and nickel to 
form light brown and light green colored complexes respectively. Yellow-light-powder solid M.P. $83{ }^{\circ} \mathrm{C}$ Solubility = Ethanol, FTIR $(\mathrm{KBr}) \mathrm{cm}^{-1}: 3425\left(v^{\mathrm{O}-\mathrm{H}}\right), 3198\left(v^{\mathrm{N}-\mathrm{H}}\right) 1431\left(v^{\mathrm{N}=\mathrm{N}}\right) 1325$ $\left(v^{\mathrm{N} \rightarrow \mathrm{O}}\right) 1224\left(v^{\mathrm{C}-\mathrm{N}}\right) 1177\left(v^{\mathrm{N}-\mathrm{N}}\right) 1482\left(v_{\mathrm{b}}^{\mathrm{N}-\mathrm{H}}\right) 1067\left(v_{\mathrm{b}}^{\mathrm{O}-\mathrm{H}}\right) 1591\left(v^{\mathrm{N}-\mathrm{O}}\right), 1349\left(v^{\mathrm{C}-\mathrm{N}}\right) .{ }^{1} \mathrm{H}$ NMR (DMSO-D6) $\delta: 12.35$ (s, 1, O-H), 7.57-8.13 (m, 9, Ar-H), Anal. Found for CHN: C; 55.02, $\mathrm{H} ; 2.97, \mathrm{~N} ; 14.36 \%$. Calcd: C; 55.46, H; 3.55, N; 14.93\%, Mass $m / z ; 281$.

\section{UV-VIS spectra of $\mathrm{Co}^{+2}$-HPTPT and $\mathrm{Ni}^{+2}$-HPTPT complexes}

HPTPT forms colored complexes with $\mathrm{Co}^{2+}$ and $\mathrm{Ni}^{2+}$. The complexation reaction of $\mathrm{Co}^{2+}$ with the ligand HPTPT was found to be faster than that of $\mathrm{Ni}^{2+}$ in the same conditions. Figure 1 shows the absorption spectra for the individual colored $\mathrm{Co}^{+2}-\mathrm{HPTPT}$ and $\mathrm{Ni}^{+2}$ HPTPT complexes overlap with each other, which interferes with the spectrophotometric determination of the ions. Therefore simultaneous determination of $\mathrm{Co}^{2+}$ and $\mathrm{Ni}^{2+}$ is possible using binary HPSAM.

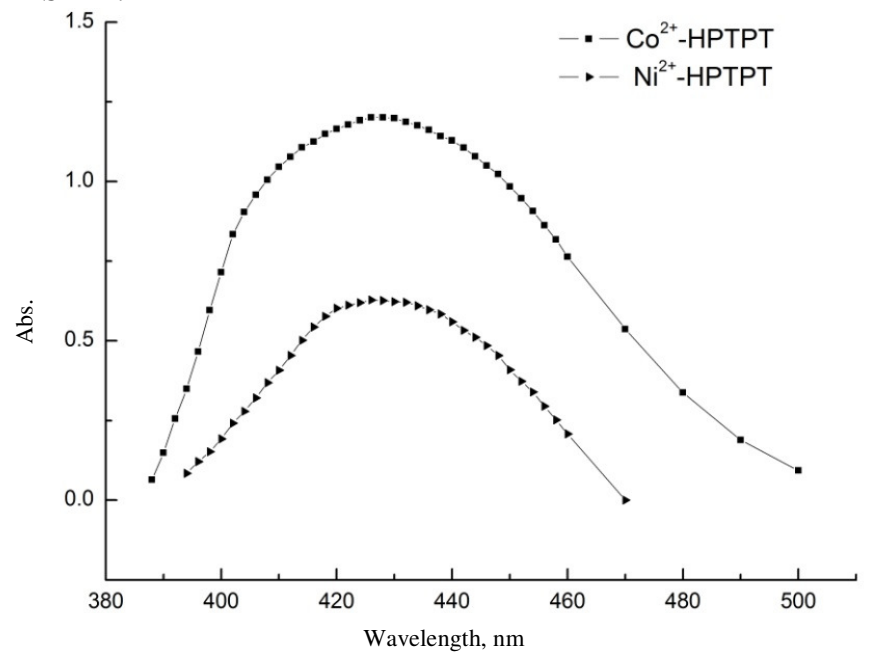

Figure 1. Absorption spectra of $\mathrm{Co}^{2+}$-HPTPT complex $\left(\mathrm{C}_{\mathrm{Co}} 5 \times 10^{-5}, \mathrm{C}_{\mathrm{HPTPT}} 5 \times 10^{-4}\right)$ and $\mathrm{Ni}^{2+}{ }_{-}$ HPTPT complex $\left(\mathrm{C}_{\mathrm{Ni}} 5 \times 10^{-5}, \mathrm{C}_{\mathrm{HPTPT}} 5 \times 10^{-4}\right)$

\section{Effect of $p H$}

The effect of $\mathrm{pH}$ of medium on the absorbance of $\mathrm{Co}^{+2}$-HPTPT and $\mathrm{Ni}^{+2}$-HPTPT complexes was studied in the $\mathrm{pH}$ range of 4.5 to 10 using tris buffer solution. The absorbance for both $\mathrm{Co}^{+2}$-HPTPT and $\mathrm{Ni}^{+2}$-HPTPT complexes increases up to 9.2 after which absorbance decreases. Therefore a $\mathrm{pH}$ range of 8-9.2 was selected for further study.

\section{Effect of reagent concentration}

The effect of the HPTPT concentration on the absorbance of $\mathrm{Co}^{2+}$-HPTPT and $\mathrm{Ni}^{2+}$-HPTPT complexes were investigated in the range of $5 \times 10^{-4}$ to $20 \times 10^{-4}$ of HPTPT at $426 \mathrm{~nm}$. The results given in Figure 2 show that the absorbance increases with increasing [HPTPT] up to $20 \times 10^{-4} \mathrm{M}$, remaining constant thereafter. Thus, HPTPT was used at a concentration of $5 \times 10^{-4} \mathrm{M}$.

\section{Effect of surfactant}

To investigate effect of surfactant on absorption spectra of cobalt and nickel complexes, individual calibration of $\mathrm{Co}^{2+}$ and $\mathrm{Ni}^{2+}$ were studied in the presence or absence of triton $\mathrm{x}-100$. The molar absorptivity for Co-HPTPT and Ni-HPTPT complexes at their $\lambda_{\max }$ were 29710 
and $9882 \mathrm{~L} \mathrm{~mol}^{-1} \mathrm{~cm}^{-1}$ respectively. In the absence of any surfactant these results were 19121 and $9705 \mathrm{~L} \mathrm{~mol}^{-1} \mathrm{~cm}^{-1}$ for $\mathrm{Co}^{2+}$ and $\mathrm{Ni}^{2+}$ respectively. These results are summarized in Table 1 and 2 . The results reveal that the use of nonionic surfactant enhances the stability and solubility of complexes in aqueous media.

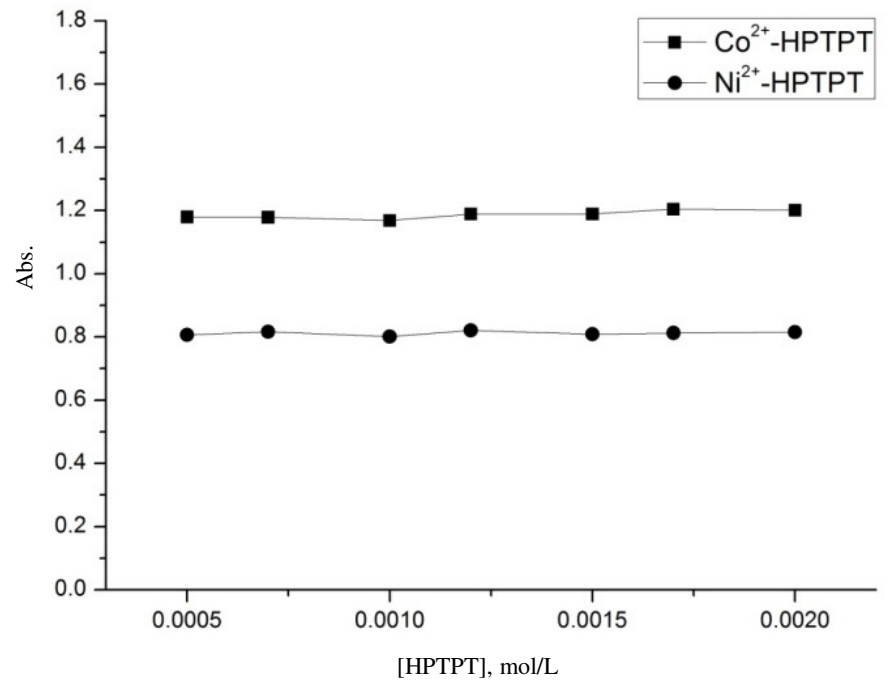

Figure 2. Effect of HPTPT conc $^{\mathrm{n}}$ on absorption spectra of $\mathrm{Co}^{2+}-\mathrm{HPTPT}$ and $\mathrm{Ni}^{2+}-\mathrm{HPTPT}$ complex

Table 1. Effect of surfactant on absorbencies of cobalt and nickel complexes

\begin{tabular}{|c|c|c|c|c|c|}
\hline \multirow{3}{*}{ S.No. } & Concentration of & \multicolumn{4}{|c|}{ Absorbance } \\
\hline & \multirow[b]{2}{*}[\mathrm{Co}/\mathrm{Ni}]{} & \multicolumn{2}{|c|}{ without surfactant } & \multicolumn{2}{|c|}{ with surfactant } \\
\hline & & $\mathrm{A}_{\mathrm{Co}}^{426}$ & $\mathrm{~A}_{\mathrm{Ni}}^{426}$ & $\mathrm{~A}_{\mathrm{Co}}^{426}$ & $\mathrm{~A}_{\mathrm{Ni}}^{426}$ \\
\hline 1 & $6 \times 10^{-6}$ & 0.32645 & 0.19236 & 0.65821 & 0.38951 \\
\hline 2 & $1 \times 10^{-5}$ & 0.41373 & 0.23947 & 0.81112 & 0.44377 \\
\hline 3 & $2 \times 10^{-5}$ & 0.6133 & 0.34063 & 1.15611 & 0.56255 \\
\hline 4 & $3 \times 10^{-6}$ & 0.7961 & 0.43778 & 1.44381 & 0.66045 \\
\hline 5 & $4 \times 10^{-6}$ & 0.9956 & 0.53169 & 1.7235 & 0.75008 \\
\hline 6 & $5 \times 10^{-6}$ & 1.1669 & 0.6205 & 1.96445 & 0.82287 \\
\hline
\end{tabular}

Table 2. Statistical analysis of $\mathrm{Co}^{2+}$ and $\mathrm{Ni}^{2+}$

\begin{tabular}{ccccc}
\hline \multirow{2}{*}{ Parameters } & \multicolumn{2}{c}{$\mathrm{Co}^{2+}$ at $426 \mathrm{~nm}$} & \multicolumn{2}{c}{$\mathrm{Ni}^{2+}$ at $426 \mathrm{~nm}$} \\
\cline { 2 - 5 } & $\begin{array}{c}\text { Without } \\
\text { triton } \mathrm{x}-100\end{array}$ & $\begin{array}{c}\text { With } \\
\text { triton X- } 100\end{array}$ & $\begin{array}{c}\text { Without } \\
\text { triton } \mathrm{x}-100\end{array}$ & $\begin{array}{c}\text { With } \\
\text { triton } \mathrm{X}-100\end{array}$ \\
\hline $\begin{array}{c}\text { Molar } \\
\text { absorptivity } \\
\left(\mathrm{L} \mathrm{mol} \mathrm{m}^{-1} \mathrm{~cm}^{-1}\right) \\
\mathrm{R}^{2}\end{array}$ & 19121.5 & 29710.94 & 9705.54 & 9882.51 \\
$\begin{array}{c}\text { Linear range } \\
\left(\mathrm{mol} \mathrm{L}^{-1}\right)\end{array}$ & 0.9991 & 0.9939 & 0.9986 & 0.989 \\
\hline
\end{tabular}




\section{H-point standard addition method}

In the proposed system, $\mathrm{Co}^{2+}$ and $\mathrm{Ni}^{2+}$ ions are the analyte and interfering ions, respectively. Figure 3 shows typical HPSAM plot for simultaneous determination of $\mathrm{Co}^{2+}$ and $\mathrm{Ni}^{2+}$ at the selected wavelengths of $\lambda_{1}=410$ and $\lambda_{2}=445 \mathrm{~nm}$, the $\mathrm{Co}^{2+}$-HPTPT complex signal increases linearly with concentration of $\mathrm{Co}^{+2}$, whereas signal for Ni-HPTPT complex does not change with the increase in analyte concentration. The concentration of $\mathrm{Co}^{2+}$ ion is determined by HPSAM using two wavelengths, whereas the concentration of $\mathrm{Ni}^{2+}$ was determined by employing the ordinate value obtained from $\mathrm{H}$ point to calibration line as shown in Figure 4.

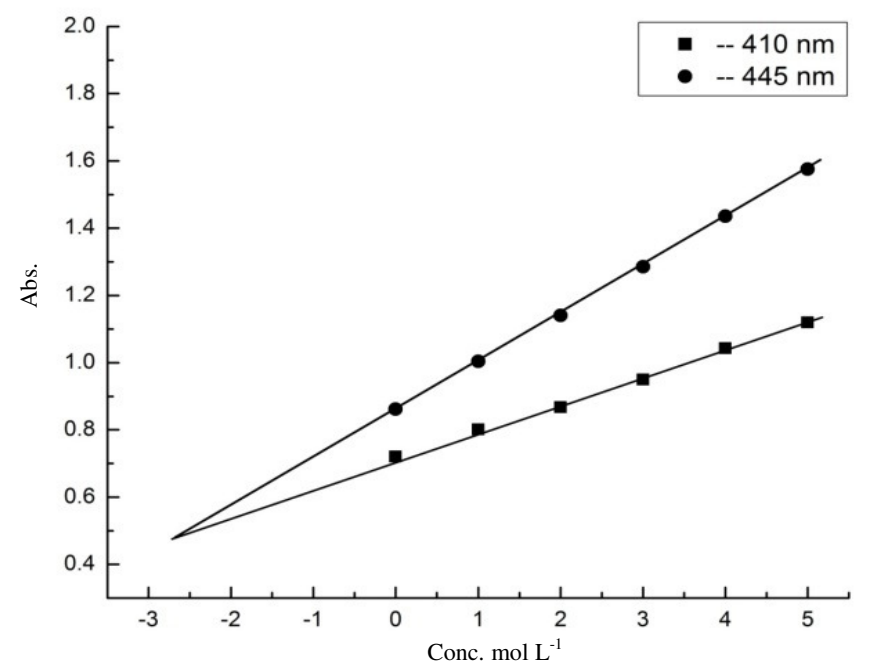

Figure 3. HPSAM plot for simultaneous determination of cobalt and nickel under optimized condition with a $\mathrm{C}_{\mathrm{Co}} 2.66 \times 10^{-5}$ and $\mathrm{C}_{\mathrm{Ni}} 1.33 \times 10^{-5}$

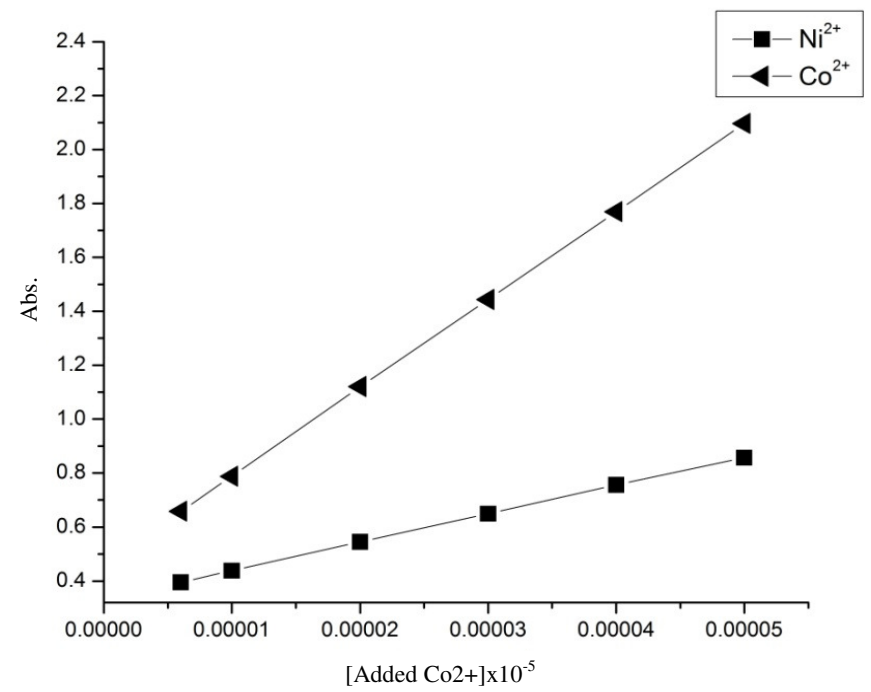

Figure 4. Calibration curve of Co-HPTPT ( 4 ) at $526 \mathrm{~nm} \&$ Ni-HPTPT (匹) complex at 426 $\mathrm{nm}, \mathrm{C}_{\mathrm{HPTPT}} 5 \times 10^{-4} \mathrm{M}, \mathrm{pH} 8$ in triton $\mathrm{x}-100(10 \% \mathrm{v} / \mathrm{v})$ 


\section{Reproducibility of the method}

Simultaneous spectrophotometric determination of cobalt and nickel under optimum conditions were performed. To investigate the reproducibility of $\mathrm{H}$ point standard addition method, five replicate experiments of binary samples of $\mathrm{Co}^{2+}$ and $\mathrm{Ni}^{2+}$ were done. The

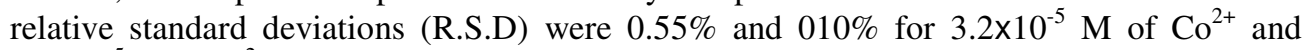
$0.8 \times 10^{-5} \mathrm{M}$ of $\mathrm{Ni}^{2+}$ respectively are presented in Table 3 .

Table 3. Results of Five replicate simultaneous determination of Cobalt and Nickel

\begin{tabular}{|c|c|c|c|}
\hline Taken & $\mathrm{mol} \mathrm{L}^{-1}$ & Found, & $\mathrm{mol} \mathrm{L}^{-1}$ \\
\hline $\mathrm{Co}^{2+}$ & $\mathrm{Ni}^{2+}$ & $\mathrm{Co}^{2+}$ & $\mathrm{Ni}^{2+}$ \\
\hline $3.2 \times 10^{-5}$ & $0.8 \times 10^{-5}$ & $3.18 \times 10^{-5}$ & $0.8 \times 10^{-5}$ \\
\hline $3.2 \times 10^{-5}$ & $0.8 \times 10^{-5}$ & $3.16 \times 10^{-5}$ & $0.79 \times 10^{-5}$ \\
\hline $3.2 \times 10^{-5}$ & $0.8 \times 10^{-5}$ & $3.18 \times 10^{-5}$ & $0.79 \times 10^{-5}$ \\
\hline $3.2 \times 10^{-5}$ & $0.8 \times 10^{-5}$ & $3.21 \times 10^{-5}$ & $0.81 \times 10^{-5}$ \\
\hline $3.2 \times 10^{-5}$ & $0.8 \times 10^{-5}$ & $3.18 \times 10^{-5}$ & $0.80 \times 10^{-5}$ \\
\hline \multicolumn{2}{|c|}{ Mean } & $3.182 \times 10^{-5}$ & $0.798 \times 10^{-5}$ \\
\hline \multicolumn{2}{|c|}{ S.D. } & $1.78 \times 10^{-7}$ & $8.36 \times 10^{-8}$ \\
\hline \multicolumn{2}{|c|}{ R.S.D. } & $0.55 \%$ & $0.10 \%$ \\
\hline
\end{tabular}

\section{Analysis of cobalt-nickel mixtures}

Three synthetic mixtures having different concentration ratios of $\mathrm{Co}^{2+}$ and $\mathrm{Ni}^{2+}$ were analyzed to test the accuracy of $\mathrm{H}$ point standard addition method for the simultaneous determination of both ions. The results are given in Table 4.

Table 4. Simultaneous determination of Co and Ni by HPSAM (Triple determination, $n=3$ )

\begin{tabular}{cccccc}
\hline \multicolumn{2}{c}{ Taken } & \multicolumn{2}{c}{ Found } & \multicolumn{2}{c}{$\%$ Recovery } \\
\hline $\mathrm{Co}^{2+}$ & $\mathrm{Ni}^{2+}$ & $\mathrm{Co}^{2+}$ & $\mathrm{Ni}^{2+}$ & $\mathrm{Co}^{2+}$ & $\mathrm{Ni}^{2+}$ \\
\hline $2.66 \times 10^{-5}$ & $1.33 \times 10^{-5}$ & $2.653 \times 10^{-5}+0.011$ & $1.32 \times 10^{-5}+0.005$ & 99.62 & 99.25 \\
$3.0 \times 10^{-5}$ & $1.00 \times 10^{-5}$ & $2.98 \times 10^{-5}+0.017$ & $0.99 \times 10^{-5}+0.011$ & 99.33 & 99.00 \\
$3.20 \times 10^{-5}$ & $0.8 \times 10^{-5}$ & $3.2 \times 10^{-5}+0.011$ & $0.79 \times 10^{-5}+0.005$ & 99.06 & 98.75 \\
\hline
\end{tabular}

Effect of foreign ions on simultaneous determination of $\mathrm{Co}^{2+}$ and $\mathrm{Ni}^{2+}$

Interference of several cations and anions in the simultaneous determination of cobalt and nickel was studied at 100, 50 and $10 \mathrm{ppm}$ level. Following diverse ions $\mathrm{Na}^{+}, \mathrm{K}^{+}, \mathrm{NH}_{4}^{+}, \mathrm{Br}^{-}, \mathrm{CH}_{3} \mathrm{COO}^{-}$, $\mathrm{NO}_{3}{ }^{-}$and $\mathrm{CO}_{3}^{-2}$ are tolerable up to $100 \mathrm{ppm}$ level, $\mathrm{Ba}^{2+}, \mathrm{F}^{-}, \mathrm{Cl}^{-}, \mathrm{I}^{-}$and $\mathrm{SO}_{4}^{-2}$ are tolerable up to $50 \mathrm{ppm}$ and $\mathrm{Sn}^{2+}, \mathrm{Al}^{3+}$ and $\mathrm{PO}_{4}^{3-}$ are also tolerable up to $10 \mathrm{ppm}$ level and some ion $\mathrm{Zn}^{2+}, \mathrm{Hg}^{2+}$, $\mathrm{Ca}^{2+}, \mathrm{Pb}^{2+}$ and $\mathrm{SCN}^{-}$are highly interfering ions are intolerable at all levels studied.

In case of the past reagents reported for spectrophotometric determination of cobalt, molar absorptivity values have been in the range of $1000-24000 \mathrm{~L} \mathrm{~mol} \mathrm{~cm}^{-1}$ for hydroxytriazenes and other reagent have slightly better value than hydroxytriazenes. The present reagent has molar absorptivity values $29710 \mathrm{~L} \mathrm{~mol} \mathrm{~cm}^{-1}$ for cobalt and $9882 \mathrm{~L} \mathrm{~mol} \mathrm{~cm}^{-1}$ for nickel in aqueous medium and is one of the most sensitive reagent among hydroxytriazenes reported. Further this is first report on the use of hydroxytriazene for simultaneous spectrophotometric determination of cobalt and nickel.

\section{References}

1. Hassler J W, Activated Carbon; Chemical Publishing Company Inc: New York, 1963. 
2. Khan S, Dashora R, Mehta A and Goswami A K, J Indian Chem Soc., 2003, 80(8), 793-794.

3. Naulakha N and Goswami A K, J Indian Chem Soc., 2004, 81(5), 438-439.

4. Paliwal K, Gorji D, Kumar S, Naulakha N, Goswami A K and Purohit D N, Asian J Chem., 2001, 13(1), 299-304.

5. Zabeen R, Goswami A K and Purohit D N, Chim Acta Turc., 1994, 22(2), 22.

6. Agency for Toxic Substances and Disease Registry (ATSDR). Public Health Service, U.S. Department of Health and Human Services, Atlanta, GA. 1992.

7. Khuhawar M Y and Lanjwani S N, J Chromatogr A, 1995, 695(1), 132; DOI:10.1016/0021-9673(94)01154-7

8. Asghari A, Ghazaghi M, Rajabi M, Behzad M and Ghaedi M, J Serb Chem Soc., 2014, 79(1), 63-76; DOI:10.2298/JSC062212081A

9. Reinaldo C de C, Santos H R D and Grinberg P, Spectrochimica Acta Part B: Atomic Spectroscopy, 2002, 57(1), 15; DOI:10.1016/S0584-8547(01)00362-7

10. Todorovska N, Karadjova I, Arpadjan S and Stafilov T, Acta Pharm., 2003, 53(2), 83-90.

11. Gharehbaghi M and Shemirani F, Anal Methods, 2012, 4, 2879-2886; DOI:10.1039/C2AY25171J

12. Miller-Ihli N J, J Agric Food Chem., 1996, 44(9), 2675-2679; DOI:10.1021/jf9506161

13. Saini N K, Mukherjee P K, Rathi M S, Khanna P P and Purohit K K, J Trace Microprobe Tech., 2002, 20(4), 539-551; DOI:10.1081/TMA-120015615

14. Rohilla R and Gupta U, J Chem., 2012, 9(3), 1357-1363; DOI:10.1155/2012/739891

15. Aghajani Z, Bordbar M, Ahari-Mostafavi M M, Rezael-Bina M and Ghasemi J, Orien J Chem., 2011, 27(3), 1005-1010.

16. Bamberger E and Renauld E, Ber., 1897, 30, 2278-2289.

17. Hura I S, Naulakha N, Goswami A K, Shrivastav M K, Indian J Microbiology, 2003, 43, 275.

18. Elkins M and Hunter L, J Chem Soc., 1938, 1346-1350; DOI:10.1039/JR9380001346 